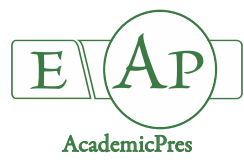

\title{
Morpho-physiological Characteristics of Basil (Ocimum basilicum L.) under NaCl-stress and Rhizophagus fasciculatum as NaCl-stress Mitigator
}

\author{
Yuneisy Milagro AGÜERO-FERNÁNDEZ, Luis Guillermo HERNÁNDEZ- \\ MONTIEL, Bernardo MURILLO-AMADOR*, José Manuel MAZÓN- \\ SUÁSTEGUI, Carlos Michel OJEDA-SILVERA, \\ Daulemys BATISTA-SÁNCHEZ
}

\begin{abstract}
Centro de Investigaciones Biológicas del Noroeste, S.C. Av. Instituto Politécnico Nacional 195, Playa Palo de Santa Rita Sur, La Paz, Baja CaliforniaSur,México;yaguero81@gmail.com; lhernandez@cibnor.mx; bmurillo@cibnor.mx(*correspondingautor); jmazon04@cibnor.mx; cojedas1979@gmail.com; daule83@gmail.com
\end{abstract}

\begin{abstract}
Salinity stress is one of the main problems limiting growth and development of cultivated species. The objective of this study was to assess $\mathrm{NaCl}$-stress basil plants (Ocimum basilicum L.) cv. 'Nufar' and to determine whether the mitigating effect of an arbuscular mycorrhizal fungus strain (AMF). A completely randomized factorial design was used considering three $\mathrm{NaCl}$ concentration (0,50 and $100 \mathrm{mM}$ ) as factor 1 and presence or absence of AMF ( 0 and $10 \mathrm{~g}$ of inoculum) as factor 2, with four replicates per treatment and four plants per repetition. The assessed response variables were, fresh and dry of aerial part and root, root length, leaf area, relative water content, water potential, plant height, number of spores and mycorrhizal colonization percentage after 20 and 50 days $\left(\mathrm{T}_{20}, \mathrm{~T}_{50}\right)$ of the experiment. The results showed greater values in all variables in the control group $(0 \mathrm{mM} \mathrm{NaCl})$ than in plants inoculated with $R$. fasciculatum with $\mathrm{T}_{20}$ and $\mathrm{T}_{50}$; although values decreased as $\mathrm{NaCl}$ concentration increased; the tendency to increase was maintained even in at 50 and $100 \mathrm{mM}$ of $\mathrm{NaCl}$ with AMF with respect to 50 and $100 \mathrm{mM} \mathrm{NaCl}$ without AMF. The AMF colonization percentage decreased as $\mathrm{NaCl}$ concentration increased. Nonetheless, the development and growth response for all variables in the inoculated plants with AMF was greater $v s$ noninoculated, which suggests that basil plant inoculation with $\mathrm{AMF}$ has a positive effect in mitigating $\mathrm{NaCl}$ stress.
\end{abstract}

Keywords: arbuscular mycorrhizal fungi (AMF); biomass; colonization; water potential

\section{Introduction}

Salinity is one of the main abiotic factors that worldwide negatively affect agriculture production (Iqbal et al., 2015). The increase of salt concentration in soil is an abiotic factor that stresses plants and decreases their capacity to absorb water, limiting important metabolic processes, affecting osmotic equilibrium, nutrient absorption, hydraulic and stomatal conductivities, raw photosynthesis rate and intracellular $\mathrm{CO}_{2}$ concentration, which directly damages plant development (Batista-Sánchez et al., 2017). Salinity stress affects water absorption in plants in the radicle area because of a decrease of osmotic potential and consequently plant soil hydration uptake (Batista-Sánchez et al., 2015). It is estimated that more than 800 million hectares have been affected by salinity around the world, which represents a loss of more than 12 billion USD annually for the agricultural industry (Khalig et al., 2014). In México, the salinization of agricultural soil affects $3.2 \%$ of its territory (SEMARNAT, 2009), with salinity problems being more frequent in dry lands where water used for irrigation is rich in salts, thus consequently causing further and progressive soil deterioration (Zamudio-González et al., 2004).

Arbuscular mycorrhizal fungi (AMF) are plant root symbionts, considered to be the cornerstone of mutualism in terrestrial ecosystems (Wimmer et al., 2016). Studies have demonstrated that AMF are capable of promoting plant growth while providing increased tolerance to soil salinity in many plants species by a use of diverse mechanisms, such as favoring nutrient acquisition, plant growth hormone production, rhizosphere development as well as improving 
1286

soil conditions (Elhindi et al., 2017). Research on AMF efficiency in increasing plant halotolerance has been performed with horticulture (Abdel-Latef and Chaoxing, 2011) and industrial (Yamato et al., 2008) cultivation, while scarce reports exist on aromatic species. From a scientific and technological point of view, it is important to study these microorganisms and their mitigating affects on salinity stress in aromatic species, such as basil and others of commercial importance.

Basil (Ocimum basilicum L.) is an aromatic plant of the family Lamiaceae that is native to southern Asia and is widely distributed in tropical and subtropical regions (Briseño et al., 2013). It is a plant species considered to have important applications in medicine and culinary areas (Makri and Kintzios, 2008). Basil has different therapeutic applications, such as the ability to reduce blood pressure and glucose and cholesterol levels in blood, also it has antiinflammatory and anti-stress properties (Tomar et al., 2010). The cultivation of this species generates important economical income for farmers, but salinity in irrigation water and soil limit production, especially of the varieties sensitive to salinity. The objective of this study was to assess the mitigating effect of arbuscular mycorrhizal fungus (Rhizophagus fasciculatum) strain in 'Nufar' cv. in basil plants subjected to $\mathrm{NaCl}$-stress during the initial growth stage.

\section{Materials and Methods}

Study area

This study was developed at the experimental field of Centro de Investigaciones Biológicas del Noroeste (CIBNOR) located $24^{\circ} 08^{\prime} 10.03 \mathrm{~N}$ and $110^{\circ} 25^{\prime} 35.31 \mathrm{~W}$ northwest of La Paz, Baja California Sur, Mexico at 7 masl. The experiment was done under a white anti-aphid meshhouse with $30 \%$ shade ( 55 mesh) and cover with a second black mesh with $35 \%$ shade (20 mesh). The experimental site has a type Bw (h') hw (e) climate, characterized as semiarid with xerophilous vegetation (García, 2004). During the experimental time, the average, maximum and minimum temperatures were 29,30 and $20^{\circ} \mathrm{C}$, respectively; average relative humidity was $69 \%$, dewpoint $22{ }^{\circ} \mathrm{C}$, showing a total precipitation of $14.6 \mathrm{~mm}$ and average solar radiation of $293.3 \mathrm{~W} \mathrm{~m}^{2}$. These variables were recorded daily using a portable meteorological station (Vantage Pro2 Davis Instruments, U.S.A.) placed inside the mesh house.

\section{Genetic material}

The seeds used were from basil 'Nufar' cv. which were provided by the $\mathrm{V}$ is Seed Company, Inc. (http://www.visseed.com/) (Arcadia, California, USA). The arbuscular mycorrhizal fungus (AMF) was a commercial strain of Rhizophagus fasciculatum which was provided by from Republic of Cuba. This strain contains about 50 to 70 spores per gram. The morphological strain description showed globose shape, hyaline colour to pale cream and could reach a run travel from 60 to 110 micrometers. The number of pairs constituted three layers (Rodríguez et al., 2004).

\section{Experimental design}

A completely randomized design with factorial arrangement was used, considering three $\mathrm{NaCl}$ concentrations $(0,50$ and $100 \mathrm{mM})$ as factor one and the presence or absence of AMF $R$. fasciculatum (control and 10 $\mathrm{g}$ of inoculum) as factor two. The factorial arrangement was $3 \times 2$ treatments with four replicates per treatment and four plants per repetition.

\section{Experimental conditions}

Seeds were previously disinfected by 5 -min immersion in a calcium hypochlorite solution containing $5 \%$ of active chlorine and subsequently washed with distilled and sterilized water. The seeds were seeded in polystyrene 200well trays with the commercial substrate previously described. To maintain substrate humidity, subsequently after sowing, daily irrigation was applied to achieve a homogeneous emergence. When seedlings reached an average height of $15 \mathrm{~cm}$, they were transplanted in $1-\mathrm{kg}$ plastic pots with the same sterilized commercial substrate according to the label, placing one plant per pot with daily application of $250 \mathrm{~mL}$ of water with $0.35 \mathrm{dS} \mathrm{m} \mathrm{m}^{-1}, \mathrm{pH} 6.7$ and nutritional solution according to Samperio (1997) and modified in P content according to Swift (2002).

\section{Spore content in the inoculum and mycorrbizal colonization percentage \\ Inoculation of $R$. fasciculatum was performed at the} moment of transplanting, applying $10 \mathrm{~g}$ of AMF to each seedling, equivalent to an average content from 50-70 spores per gram of the product. The colonization percentage was assessed 50 days subsequent to $\mathrm{NaCl}$ treatment. Previous to inoculation, the spores were extracted following the wet sieving and decanting method described by Daniels and Skipper (1982) and modified by Utobo et al. (2011). Colonization percentage was calculated by the methodology described by Hashem et al. (2014) through the following formula:

Colonization percentage $=$ Total colonized segments/Total studied segments $\times 100$.

\section{$\mathrm{NaCl}$ treatments}

One week after transplanting, $\mathrm{NaCl}$ was gradually applied according to the proposed experimental design and the methodology of Murillo-Amador et al. (2007), applying daily $250 \mathrm{~mL}$ of the corresponding solution to each pot. This amount was enough to drain and avoid $\mathrm{NaCl}$ accumulation in the substrate. This was confirmed when electrical conductivity (CE) and $\mathrm{pH}$ of drained water were measured and then compared with $\mathrm{CE}$ and $\mathrm{pH}$ of the original $\mathrm{NaCl}$ concentration during the experimental period.

\section{Morphometric variables}

The first and second biomass production measurement was performed 20 and 50 days after applying the $\mathrm{NaCl}$ treatments. The samples collected were transferred to the plant physiology laboratory. The leaf area $\left(\mathrm{cm}^{2}\right)$ was determined by integrated leaf area (Li-Cor, Model-LI3000A, series PAM 1701, USA). Fresh and dry biomass (g) 
were measured with an analytical balance (Mettler Toledo, Model AG204, USA). Dry biomass was obtained by placing leaves and stems in paper bags that were introduced into an oven (Shel-Lab, Model FX-5, series-1000203, USA) at a temperature of $70 \quad{ }^{\circ} \mathrm{C}$ until a constant weight (approximately $72 \mathrm{~h}$ ). Total biomass crop was performed at day 50 , which included the collection of the complete plant and separation of leaves, stems and roots. The plant height $(\mathrm{cm})$, root length $(\mathrm{cm})$, fresh and dry biomass $(\mathrm{g})$ of the aerial part (leaves and stems), root and foliar area $\left(\mathrm{cm}^{2}\right)$ were measured.

\section{Physiological variables}

Relative water content (RWC) was assessed 20 and 50 days after applying $\mathrm{NaCl}$ treatments, following Yamasaki and Dillenburg (1999) method. Leaves were collected from the middle part of each plant to avoid decreasing age effect. The collected samples were transferred to the laboratory where three disks of $3.14 \mathrm{~cm}^{2}$ of each leaf were cut with a hole puncher (Model DIN 7200, México); then, the disks were subsequently weighed to obtain fresh $(\mathrm{FW})$ and turgid (TW) weights. Turgid was obtained by placing the disks in distilled water inside a Petri dish and during this process (imbibition), the disks were weighed periodically after eliminating surface water with absorbent paper. At the end of the imbibition process, the disks were placed in an oven at $80^{\circ} \mathrm{C}$ during $48 \mathrm{~h}$ to get the dry weight (DW). Fresh, turgid and dry weights were obtained using an analytical balance with $0.0001 \mathrm{~g}$ precision (Mettler Toledo, Model AG204, USA). The relative water content (RWC \%) was calculated using the values of FW, TW and DW using the following equation:

$$
R W C(\%)=\frac{(\mathrm{FW}-\mathrm{DW})}{(\mathrm{TW}-\mathrm{DW}} \times 100
$$

Water potential $\left(\Psi_{\mathrm{w}}\right)$ was measured 20 and 50 days after applying the $\mathrm{NaCl}$ treatments. The leaves were collected at the most critical hour $(12: 00 \mathrm{~h})$, considering the interval in which the highest temperatures were recorded during the day. The $\Psi_{\mathrm{w}}(\mathrm{MPa})$ was determined with a water potential meter (Dewpoint Water Potential Meter Model WP4-T, Decagon Devices, USA) for soil and botanical samples (grains, seeds, leaves, plant tissues in general), which functioned according to the dew point principle with sensors, a condensation mirror an infrared light. Starting from the collected leaves, disks of $9.60 \mathrm{~cm}^{2}$ were obtained by using a hole puncher (Model DIN 7200, México), and subsequently each disk was placed inside the equipment bucket.

\section{Statistical analysis}

Analyses of variance (ANOVA) and multiple comparison of means (Tukey HSD $p=0.05$ ) were performed using Statistica v. 10.0 for Windows (StatSoft, 2011).

\section{Results}

Morpho-physiological variables assessed at day 20 after applying $\mathrm{NaCl}$

The analysis of the interaction factors ( $\mathrm{NaCl} \times \mathrm{AMF})$ showed that fresh and dry biomass of the aerial part (FBAP and DBAP) and leaf area (LA) decreased as $\mathrm{NaCl}$ concentrations increased, showing highest values at $0 \mathrm{mM}$ $\mathrm{NaCl}$ in plants inoculated with AMF and lowest in those subjected to $100 \mathrm{mM}$ of $\mathrm{NaCl}$ without AMF; nonetheless, fresh and dry biomass and leaf area increased in 50 and 100 $\mathrm{mM}$ of $\mathrm{NaCl}$ with AMF compared to 50 and 100 without AMF (Table 1).

The factor interaction analysis showed that water potential $\left(\Psi_{\mathrm{w}}\right)$ values were less negative in plants subjected to $0 \mathrm{mM} \mathrm{NaCl}$ and inoculated with AMF and most negative values in those subjected to $100 \mathrm{mM} \mathrm{NaCl}$ without AMF. The $\Psi_{\mathrm{w}}$ showed lowest negative values in 50 and 100 $\mathrm{mM}$ of $\mathrm{NaCl}$ with AMF compared with 50 and 100 without AMF (Table 1). The effect of applying $\mathrm{NaCl}$ on relative water content (RWC) showed a greatest RWC at 0 $\mathrm{mM} \mathrm{NaCl}$ with AMF but decreased at $100 \mathrm{mM} \mathrm{NaCl}$ without AMF (Table 1).

\section{Morpho-physiological variables assessed on day 50 (crop) after applying $\mathrm{NaCl}$ \\ The interaction factors $(\mathrm{NaCl} \times \mathrm{AMF})$ analysis showed that plant height $(\mathrm{PH})$, root length (RL) fresh and dry biomass of aerial part (FBAP and DBAP), fresh and dry root biomass (FRB and DRB) and leaf area (LA) decreased as $\mathrm{NaCl}$ concentrations increased. These variables showed highest values in those plants treated with $0 \mathrm{mM} \mathrm{NaCl}$ with AMF and lowest in those plants subjected to $100 \mathrm{mM} \mathrm{NaCl}$}

Table 1. Effect of NaCl-stress on morpho-physiological characteristics of basil plants at 20-days treatment $\left(\mathrm{T}_{20}\right)$ and inoculated with an arbuscular mycorrhizal fungus (Rhizophagus fasciculatum) strain as $\mathrm{NaCl}$-stress mitigator

\begin{tabular}{|c|c|c|c|c|c|c|}
\hline $\mathrm{NaCl}(\mathrm{mM})$ & $\operatorname{AMF}(\mathrm{g})$ & FBAP $(\mathrm{g})$ & DBAP $(\mathrm{g})$ & $\mathrm{LA}\left(\mathrm{cm}^{2}\right)$ & $\Psi_{\mathrm{w}}(\mathrm{MPa})$ & RWC (\%) \\
\hline 0 & AMF & $97.05 \pm 2.47 \mathrm{a}$ & $17.10 \pm 0.64 a$ & $1655.25 \pm 22.05 a$ & $-0.12 \pm 0.07 \mathrm{a}$ & $97.11 \pm 2.37 \mathrm{a}$ \\
\hline 50 & & $66.61 \pm 2.33 b$ & $9.20 \pm 0.16 \mathrm{c}$ & $1220.21 \pm 15.94 \mathrm{c}$ & $-1.35 \pm 0.25 b c$ & $86.71 \pm 1.69 b$ \\
\hline 100 & & $56.86 \pm 1.46 c$ & $7.65 \pm 0.51 \mathrm{~d}$ & $1005.36 \pm 32.53 \mathrm{~d}$ & $-1.75 \pm 0.15 c$ & $81.52 \pm 5.08 \mathrm{~b}$ \\
\hline 0 & Non-AMF & $67.99 \pm 6.29 b$ & $11.20 \pm 1.26 \mathrm{~b}$ & $1413.54 \pm 49.73 b$ & $-0.76 \pm 0.32 b$ & $82.84 \pm 0.89 b$ \\
\hline 50 & & $53.00 \pm 1.46 \mathrm{c}$ & $8.55 \pm 0.36 \mathrm{~d}$ & $1160.51 \pm 72.16 \mathrm{~d}$ & $-1.49 \pm 0.22 \mathrm{c}$ & $81.75 \pm 1.64 b$ \\
\hline 100 & & $43.79 \pm 5.52 \mathrm{~d}$ & $7.20 \pm 0.14 \mathrm{e}$ & $948.55 \pm 110.64 \mathrm{e}$ & $-2.71 \pm 0.42 \mathrm{~d}$ & $66.47 \pm 0.64 c$ \\
\hline Significance level & & *** & $* * *$ & $* * *$ & * & ** \\
\hline
\end{tabular}

$\mathrm{NaCl}=$ Sodium chloride $(\mathrm{mM}), \mathrm{AMF}=$ arbuscular mycorrhizal fungus $(\mathrm{AMF}=$ with $\mathrm{AMF}, \mathrm{Non}-\mathrm{AMF}=$ without $\mathrm{AMF}), \mathrm{FBAP}=$ fresh biomass of aerial part $(\mathrm{g}), \mathrm{DBAP}=$ dry biomass of aerial part $(\mathrm{g}), \mathrm{FA}=$ leaf area $\left(\mathrm{cm}^{2}\right), \Psi_{\mathrm{w}}=$ water potential $(\mathrm{MPa}), \mathrm{RWC}=$ relative water content $(\%)$. Average and standard deviation values with different letters in the same column are statistically different (Tukey HSD, $p=0.05)$. Level of significance of ANOVA: ${ }^{*}=P \leq 0.05 .^{* *}=P \leq 0.01 .{ }^{* * *}=P \leq 0.001(\mathrm{media} \pm \mathrm{SD})$. 
Table 2. Effect of NaCl-stress on morpho-physiological characteristics of basil plants at 50-days treatment $\left(\mathrm{T}_{20}\right)$ and inoculated with an arbuscular mycorrhizal fungus (Rhizophagus fasciculatum) strain as $\mathrm{NaCl}$-stress mitigator

\begin{tabular}{|c|c|c|c|c|c|c|}
\hline $\begin{array}{l}\mathrm{NaCl} \\
(\mathrm{mM})\end{array}$ & $\begin{array}{c}\text { AMF } \\
\text { (g) }\end{array}$ & $\begin{array}{l}\mathrm{PH} \\
(\mathrm{cm})\end{array}$ & $\begin{array}{l}\mathrm{RL} \\
(\mathrm{cm})\end{array}$ & $\begin{array}{c}\text { FBAP } \\
(\mathrm{g})\end{array}$ & $\begin{array}{c}\text { DBAP } \\
(\mathrm{g})\end{array}$ & $\begin{array}{c}\text { FRB } \\
(\mathrm{g})\end{array}$ \\
\hline 0 & AMF & $45.25 \pm 0.96 a$ & $40.50 \pm 0.58 \mathrm{a}$ & $146.27 \pm 4.99 a$ & $36.00 \pm 1.10 \mathrm{a}$ & $125.08 \pm 6.60 \mathrm{a}$ \\
\hline 50 & & $35.75 \pm 0.50 \mathrm{~b}$ & $31.50 \pm 1.29 b c$ & $94.01 \pm 2.19 \mathrm{c}$ & $18.62 \pm 0.82 \mathrm{~b}$ & $95.65 \pm 4.59 \mathrm{~b}$ \\
\hline 100 & & $29.75 \pm 0.96 \mathrm{c}$ & $29.75 \pm 0.50 \mathrm{c}$ & $86.19 \pm 1.35 c$ & $15.75 \pm 0.62 c$ & $81.07 \pm 2.60 c$ \\
\hline 0 & Non-AMF & $36.75 \pm 0.50 \mathrm{~b}$ & $32.00 \pm 0.82 \mathrm{~b}$ & $114.69 \pm 6.71 \mathrm{~b}$ & $17.65 \pm 0.95 b$ & $97.95 \pm 1.43 \mathrm{~b}$ \\
\hline 50 & & $26.75 \pm 2.22 \mathrm{~d}$ & $30.25 \pm 0.50 \mathrm{c}$ & $74.77 \pm 5.14 \mathrm{~d}$ & $14.15 \pm 0.37 \mathrm{c}$ & $92.42 \pm 5.31 b c$ \\
\hline 100 & & $25.00 \pm 1.41 \mathrm{~d}$ & $27.50 \pm 1.29 \mathrm{~d}$ & $65.86 \pm 4.26 \mathrm{~d}$ & $11.72 \pm 0.43 \mathrm{~d}$ & $69.87 \pm 7.32 \mathrm{~d}$ \\
\hline Significance level & & $* *$ & $* * *$ & $*$ & $* * *$ & $* * *$ \\
\hline $\mathrm{NaCl}$ & AMF & $\overline{D R B}$ & $\mathrm{FA}$ & RWC & $\Psi_{w}$ & Col \\
\hline$(\mathrm{mM})$ & $(\mathrm{g})$ & $(\mathrm{g})$ & $\left(\mathrm{cm}^{2}\right)$ & $(\%)$ & $(\mathrm{MPa})$ & $(\%)$ \\
\hline 0 & AMF & $27.53 \pm 4.79 a$ & $2775.25 \pm 162.10 \mathrm{a}$ & $96.00 \pm 2.13 \mathrm{a}$ & $-0.24 \pm 0.05 a$ & $64.50 \pm 3.00 \mathrm{a}$ \\
\hline 50 & & $10.75 \pm 0.74 \mathrm{~b}$ & $1401.30 \pm 73.75 c$ & $73.96 \pm 2.80 \mathrm{a}$ & $-0.70 \pm 0.14 \mathrm{~b}$ & $56.25 \pm 4.35 b$ \\
\hline 100 & & $10.02 \pm 0.53 b$ & $1230.35 \pm 54.96 \mathrm{~cd}$ & $63.54 \pm 2.90 \mathrm{a}$ & $-1.09 \pm 0.03 \mathrm{~cd}$ & $46.50 \pm 2.08 \mathrm{c}$ \\
\hline 0 & Non-AMF & $11.35 \pm 1.27 \mathrm{~b}$ & $2254.18 \pm 213.51 b$ & $86.60 \pm 3.73 a$ & $-0.92 \pm 0.10 \mathrm{c}$ & -.- \\
\hline 50 & & $9.52 \pm 0.74 b$ & $1308.16 \pm 48.14 \mathrm{~cd}$ & $64.04 \pm 1.44 a$ & $-1.03 \pm 0.01 \mathrm{c}$ & --- \\
\hline 100 & & $8.00 \pm 1.30 \mathrm{c}$ & $1080.36 \pm 24.45 \mathrm{~d}$ & $56.72 \pm 2.91 \mathrm{a}$ & $-1.25 \pm 0.05 \mathrm{~d}$ & --- \\
\hline Significance level & & ${ }^{* * *}$ & $* * *$ & $n s$ & $* * *$ & $* * *$ \\
\hline
\end{tabular}

without AMF. Water potential $(\Psi \mathrm{w})$ had lower negative values at $0 \mathrm{mM}$ followed by $50 \mathrm{mM} \mathrm{NaCl}$, both with AMF while the most negative values were showed at $100 \mathrm{mM}$ $\mathrm{NaCl}$ without AMF (Table 2).

Relative water content did not show significant differences among $\mathrm{NaCl}$ concentrations; although, the highest values were at $0 \mathrm{mM}$ with and without $\mathrm{AMF}$, followed by 50 with and without AMF (Table 2).

\section{Mycorrhizal colonization percentage}

The mycorrhizal colonization percentage decreased as $\mathrm{NaCl}$ increased, which was highest in control $(0 \mathrm{mM})$ and decreased at 50 and $100 \mathrm{mM} \mathrm{NaCl}$ (Table 2).

\section{Discussion}

Previous studies have been reported that in saline soils, AMF increased nutrient intake in plants, especially $\mathrm{P}$ with precipitates of $\mathrm{Ca}^{2+}, \mathrm{Mg}^{2+}$ and $\mathrm{Zn}^{2+}$ ions (Porras-Soriano $e t$ al., 2009). In addition to nutritional improvement, AMF benefits physiological processes, such as water absorption when roots hydraulic conductivity increases and improves the osmotic balance of adaptation and carbohydrates composition (Sharifia et al., 2007). Salinity affects plant development from reducing growth due to photosynthesis alteration, enzymatic activity and ionic homeostasis to increasing plant death (Fatma et al., 2014). However, in the present study, a favorable response was observed in basil 'Nufar' cv. which confirmed that AMF inoculation was efficient in mitigating $\mathrm{NaCl}$-stress as was reported by Hashem et al. (2015) and Mendes et al. (2016). In other species such as Cucurbita pepo var. pepo cultivated under drought and salinity conditions, the application of a mixed inoculum and a consortium of six AMF native species of the
Sonoran Desert, improved dry weight of the shoot and root, foliar humidity percentage, water and osmotic potential, and radicle colonization percentage, while also decreasing physiological stress caused by drought and salinity, thus AMF inoculation was an efficient alternative as a mitigate agent in salinity stress (Harris-Valle et al., 2011). In lettuce (Lactuca sativa L.), AMF inoculation also showed a mitigating effect with salinity (Aroca et al., 2013). This effect has been associated to the mitigating effect of AMF because their associations with plants improve functions that improve efficiency of nutrients in the radicle area, starting from an increase in the volume of the soil explored, increase in toxin resistance, translocation and solubilization of essential elements and increase in tolerance to adverse abiotic conditions, such as drought and salinity (Evelin et al., 2013). The results showed in the present study could be attributed to AMF which increased the root contact area with soil, assuring continuity among the absorbent radicle surface and soil solution, optimizing soil interaction with roots (Jurkiewics et al., 2010). According to Hajiboland et al. (2010), the AMF are characterized by forming structures in the shape of a miniature tree in the radicle parenchyma cells, a structure called "arbuscule", which is the exchange site between the plant and fugus. Moreover, the mycorrhizal system is formed by a set of hyphas (mycelium) that are connected to the root tissue and branch out in soil. The mycelium found in soil forms a hypha net capable of interconnecting roots and allowing water and nutrient flux between them. These stimulating AMF functions improved the plant water state, which was observed in the relative water content, which increased in plants basil inoculated with AMF in the present study.

Basil plants response in the present study was related to morphometric, nutritional and physiological changes 
induced in colonized plants contributing to increase their resistance to abiotic tension. These results are similar to those reported previously by Alqarawi et al. (2014) where they pointed out that AMF modified the root architecture, allowing a greater range for water and essential elements in soil than in plants stressed without AMF. Moreover, AMF also mitigated salinity stress by improving absorption and nutrient capture rhizosphere conditions (Parra-Rivero et al., 2014); photosynthetic activity and water use efficiency (Hajiboland et al., 2010); compatible solute accumulation and antioxidant enzyme production (Evelin et al., 2013). Most recently, Elhindi et al. (2017) reported an increase in growth, chlorophyll content, gas exchange, photosynthetic efficiency, proline content, water use efficiency and nutrient absorption in sweet basil plants subjected to salinity stress ( 5 and $10 \mathrm{dS} \mathrm{m} \mathrm{m}^{-1}$ ) and inoculated with AMF Glomus deserticola, which favored greater growth, vigor and general cultivation productivity. In other species such as Solanum lycopersicum subject to salinity stress and inoculated with Glomus cubense, Mujica-Pérez and Fuentes-Martínez (2012) observed an increase in plant height, number of flowers and fruit and yield. In Dianthus caryophyllus, an ornamental species, Navarro et al. (2012) reported a beneficial effect in plant growth, number and size of flowers, leaves and concluded that the use of mycorrhizal (Glomus intraradices, GII and GIII) was efficient in mitigating $\mathrm{NaCl}$ stress $\left(1,3\right.$, and $6 \mathrm{dS} \mathrm{m} \mathrm{m}^{-1}$ ). In citric plants (Poncirus trifoliata) subjected to $\mathrm{NaCl}$-stress $(0$ and $100 \mathrm{mM})$ and inoculated with Glomus mosseae and Glomus vesiforme, an increase in growth was observed in plants inoculated with AMF compared with those in the control group without inoculation (Qiang-Sheng et al., 2010). Different studies maintain and conclude that AMF strains mitigate $\mathrm{NaCl}$ stress in different plant species. Some AMF strains that have shown efficiency as $\mathrm{NaCl}$-stress mitigators are Funneliformis caledonius, Funneliformis mosseae and Rhizophagus irregularis, among others with positive effects in several species, such as Fragaria ananassa Duch that has shown increases in leaves and shoots biomass, root length and biomass (Sinclair et al., 2014). The increase in nutrient absorption such as $\mathrm{P}$ and water even in abiotic tension, reduced $\mathrm{Na}$ and $\mathrm{Cl}$ absorption, affecting movement into the aerial parts (leaves and shoots) of the plant augmented water catchment maintained ionic equilibrium to improve nutrient absorption and stimulated selective catchment (Evelin et al., 2012); increased synthesis and efficiency of some enzymes (Wu et al., 2010) as proline (Ibrahim et al., 2011) and caused osmotic adjustment that maintained turgid pressure in leaves, improving equilibrium among photosynthesis, transpiration, water use efficiency and stomatal conductance in inoculated plants (Evelin et al., 2009). Likewise, AMF have improved rhizosphere soil characteristics and root architecture (Hodge and Storer, 2015). The results of the present study are in agreement with those reported by Al-Khaliel (2010), bsince AMF improved plant development benefiting nutrient absorbance and soil structure; had a direct effect in the quality of the soil while causing aggregates that improve humidity retention, such as increasing soil water potential and favoring water and nutrient absorption. These changes stimulate plant growth, hydraulic conductivity and decrease toxic ion effect induced by salinity (Seema and Garampalli, 2015). The response in basil can be attributed to the combination of physical, nutritional and cellular effects as reported previously by Ruiz-Lozano and Aroca (2010). Other studies have also demonstrated that fungus-host plant symbiosis altered water movement rate within and outward from the plants in other species, affecting water relationships and physiology (Ruiz-Lozano et al., 2006). Moreover, AMF have stimulated physiological mechanisms that increase plant stress tolerance and have the potential to increase growth in normal and induced environmental stress conditions (Abd-Allah et al., 2015a, b). Previous studies showed significantly higher values in plant height, stem diameter, leaf area, total plant leaf number and total dry weight where AMF (Rhizophagus intraradices) was used in Vitis vinifera L. plants subjected to three salinity levels $\left(0.65,1.56\right.$ and $\left.4.68 \mathrm{dS} \mathrm{m}^{-1}\right)$ compared with those noninoculated (Khalil, 2013).

As expected, no colonization was observed in those noninoculated basil plants since a sterile substrate were used, which did not allow the development of native species capable of colonizing basil plants. Then, in this study an authentic colonization was observed in the inoculated basil plants; nonetheless, colonization percentage decreased as $\mathrm{NaCl}$ increased. This result did not affect the benefit reported by this endophyte species, such as basil, which was evident in the increase in the assessed variables in inoculated AMF basil plants. These results are similar to those reported by Harris-Valle et al. (2011) where they found that mycorrhizal colonization of a mixed native AMF inoculum, decreased physiological stress (drought and salinity) in Cucurbita pepo var. pepo; nevertheless, mycorrhizal colonization decreased as salinity increased, which did not affect plant response in such a condition. According to Rivera et al. (2003) colonization percentage is representative of arbuscular mycorrhizal symbiosis functionality. The fact that inoculated AMF has survived, adapted and established under different habitats, indicates that it has a favorable influence in the rhizosphere and substrate conditions where basil plants were established. In arbuscular mycorrhizal symbiosis no threshold colonization value occurs in roots to produce plant growth improvement. This effect depends on plant and fungal species in symbiosis and specific cultivation conditions. The principle mechanism is generally assumed to be that a greater root colonization rate by the fungus improves AMF effects on growth and plant development (Seema and Garampalli, 2015).

\section{Conclusions}

The basil plants inoculated with AMF showed increases in their morpho-physiological variables even under $\mathrm{NaCl}$ stress conditions, showing a degree of infectivity and effectiveness of the AMF strain in the rhizosphere zone and in the growing conditions. The percentage of colonization decreased as the $\mathrm{NaCl}$ concentrations increased, being highest in the control $(0 \mathrm{mM})$ and decreasing in 50 and 100 $\mathrm{mM} \mathrm{NaCl}$. As expected, no colonization occurred in those non-inoculated basil plants, because of a sterile substrate was used, which did not allow for the development of native 
1290

species capable of colonizing the basil plants. The substrate used was suitable both for the development of the AMF strain and for the basil plants, as well as the number of inoculum spores.

\section{Acknowledgements}

This study was funded by "Modelo de aprovechamiento y eficiencia máxima de agua salinizada acoplado a un sistema unidireccional de acuaponia-agricultura" (CONACYTPN-2017-I-4631) and CIBNOR projects PAZAAGROT1 and 143C, SEP-CONACYT 236240 and SEPCONACYT 258282. The authors are grateful to CIBNOR technical staff, José Raymundo Ceseña-Nuñez, Adrián Jordán-Castro and Manuel Salvador TrasviñaCastro. Thanks also to Dr. Michael Matson and Diana Dorantes for editorial services in English.

\section{Authors' Contribution}

YMAF, BMA and LGHM, designed the experiment. YMAF, DSB and CMOS contributed in the assembly of experiment in agricultural area, collection of samples and transfer to the laboratory. YMAF, DSB, and CMOS participated with laboratory analysis, data and preparation of manuscripts. LGHM and JMMS contributed with reagents another laboratory and field materials. BMA analyzed the data. YMAF and BMA wrote and edited the first draft of the manuscript. BMA wrote the final version of the manuscript. All authors read and approved the final manuscript.

\section{Conflict of Interest}

The authors declare that there are no conflicts of interest related to this article.

\section{References}

Abd-Allah EF, Abeer-Hashem AA, Alqarawi AH, Alwhibi MS (2015b). Alleviation of adverse impact of salt in Phaseolus vulgaris L. by arbuscular mycorrhizal fungi. Pakistan Journal of Botany 47(3):1167-1176.

Abd-Allah EF, Abeer-Hashem AA, Alqarawi AH, Bahkali, Alwhibi MS (2015a). Enhancing growth performance and systemic acquired resistance of medicinal plant Sesbania sesban (L.) Merr using arbuscular mycorrhizal fungi under salt stress. Saudi Journal of Biological Sciences 22(3):274-283.

Abdel-LatefAA, Chaoxing H (2011). Effect of arbuscular mycorrhizal fungi on growth, mineral nutrition, antioxidant enzymes activity and fruit yield of tomato grown under salinity stress. Scientia Horticulturae 127(3):228-233.

Al-Khaliel AS (2010). Effect of salinity stress on mycorrhizal association and growth response of peanut infected by Glomus mosseae. Plant, Soil and Environment 56(7):318-324.

Alqarawi AA, Hashem A, Abd-Allah EF, Alshahrani TS, Al-Huail AA (2014). Effect of salinity on moisture content, pigment system, and lipid composition in Ephedraalata Decne. Acta Biologica Hungarica
65(1):61-71.

Aroca R, Ruiz-Lozano JM, Zamarreño AM, Paza JA, Garcia-Mina JM, Pozo MJ, Lopez-Raeza JA (2013). Arbuscular mycorrhizal symbiosis influences strigolactone production under salinity and alleviates salt stress in lettuce plants. Journal of Plant Physiology 170(1):47-55.

Batista-Sánchez D, Murillo-Amador B, Nieto-Garibay A, Alcaráz-Meléndez L, Troyo-Dieguéz E, Hernández-Montiel LG, Ojeda-Silvera CM (2017). Mitigación de $\mathrm{NaCl}$ por efecto de un bioestimulante en la germinación de Ocimum basilicum L [Mitigation of $\mathrm{NaCl}$ by the effect of a biostimulant on the germination of Ocimum basilicum L.]. Terra Latinoamericana 35(4):309-320.

Batista-Sánchez D, Nieto-Garibay A, Alcaraz-Meléndez L, Troyo-Diéguez E, Hernández-Montiel LG, Ojeda-Silvera CM, Murillo-Amador B (2015). Uso del FitoMas-E como atenuante del estrés salino $(\mathrm{NaCl})$ durante la emergencia y crecimiento inicial de Ocimum basilicum L [Use of FitoMas- $\mathrm{E}^{\oplus}$ as an attenuator of saline stress $(\mathrm{NaCl})$ during the emergence and initial growth of Ocimum basilicum L.]. Revista Electrónica Nova Scientia 7(15):265-284.

Bremner JM (1965). Total nitrogen. Methods of soil analysis. Part 3. Agronomy 5. American Society of Agronomy. Madison, Wisconsin, U.S.A.pp 1091-1100.

Briseño-Ruiz SE, Aguilar-García M, Villegas-Espinoza JA (2013). El cultivo de la albahaca [The cultivation of basil] Edit. Centro de Investigaciones Biológicas del Noroeste,S.C.LaPaz, Baja California Sur, México pp 33.

Castellanos JZ, Uvalle-Bueno JX, Aguilar-Santelises A (2000). Manual de interpretación de análisis de suelo y agua. Universidad Autónoma de Chapingo [Interpretation manual for soil and water analysis. Autonomous University ofChapingo]. Estado de México pp 9497.

Cheng KL, Bray RH (1951). Determination of calcium and magnesium in soil and plant material. Soil Science 72(6):449-458.

Daniels BA, Skipper HD (1982). Methods for the recovery and quantitative estimation of propagules from soil. In: Schenck NC (Ed). Methods and principles of mycorrhizal research. St. Paul, MN, The American Phytopathological Society pp 29-36.

Elhindi KM, El-Din AS, Elgorban AM (2017). The impact of arbuscular mycorrhizal fungi in mitigating salt-induced adverse effects in sweet basil (Ocimum basilicum L.). Saudi Journal of Biological Sciences 24(1):170179.

Evelin H, Giri B, Kapoor R (2012). Contribution of Glomus intraradices inoculation to nutrient acquisition and mitigation of ionic imbalance in $\mathrm{NaCl}$ stressed Trigonella foenum graecum. Mycorrhiza 22(3):203-217.

Evelin H, Giri B, Kapoor R (2013). Ultrastructural evidence for AMF mediated salt stress mitigation in Trigonella foenum-graecum. Mycorrhiza23(1):71-86.

Evelin H, Kapoor R, Giri B (2009). Arbuscular mycorrhizal fungi in alleviation of salt stress: a review. Annals of Botany 104(7):1263-1280.

Fatma M, Masood MAA, Khan NA (2014). Excess sulfur supplementation improves photosynthesis and growth in mustard under salt stress through increased production of glutathione. Environmental and Experimental Botany 107:55-63.

García E (2004). Modificaciones al sistema de clasificación climática de Köppen. Instituto de Geografia. Universidad Nacional Autónoma de México, México pp 98. 
Hajiboland R, Aliasgharzadeh N, Laiegh SF, Poschenreider C (2010). Colonization with arbuscular mycorrhizal fungi improves salinity tolerance of tomato (Solanum lycopersicum L.) plants. Plant and Soil 331(1-2):313-327.

Harris-Valle C, Esqueda M, Valenzuela- Soto E, Castellanos A (2011). Tolerancia a sequía y salinidad en Cucurbita pepo. var.pepo asociado con hongos micorrízicos arbusculares del desierto sonorense. Agrociencia 45(8):959-970.

Hashem A, Abd-Allah EF, Alqarawi AA, Dilfuza E (2015). Induction of salt stress tolerance in cowpea (Vigna unguiculata L.) Walp by arbuscular mycorrhizal fungi. Legume Research 38(5):579-58.

Hashem A, Abd-Allah EF, Alqarawi AA, El-Didamony G, Alwhibi Mona S, Egamberdieva D, Ahmad P (2014). Alleviation of adverse impact of salinity on faba bean (Vicia faba L.) by arbuscular mycorrhizal fungi. Pakistan Journal of Botany 46(6):2003-2013.

Hodge A, Storer K (2015). Arbuscular mycorrhiza and nitrogen: implications for individual plants through to ecosystems. Plant and Soil 386(1-2):1-19.

Ibrahim AH, Abdel-Fattah GM, Eman FM, Abd El-Aziz MH, Shohr AE (2011). Arbuscular mycorrhizal fungi and spermine alleviate the adverse effects of salinity stress on electrolyte leakage and productivity of wheat plants. New Phytologist 51(2):261-276.

Iqbal N, Umar S, Khan NA (2015). Nitrogen availability regulates proline and ethylene production and alleviates salinity stress in mustard (Brassica juncea).Journal of Plant Physiology 178:84-91.

Jurkiewicz A, Ryszka P, Anielska T, Waligórski P, Białońska D, Góralska K, ... Turnau K (2010). Optimization of culture conditions of Arnica montana L effects of mycorrhizal fungi and competing plants. Mycorrhiza 20(5):293-306.

Khalig S, Vllah Z, Athar H, Khal R (2014). Physiological and biochemical basis of salt tolerance in Ocimum basilicum L. Journal of Medicinal Plants Studies 2(1):18-27.

Khalil HA (2013). Influence of vesicular-arbuscular mycorrhizal fungi (Glomus spp.) on the response of grapevines rootstocks to salt stress. Asian Journal ofCropScience 5(4):393-404.

Makri O, Kintzios S (2008). Ocimum sp. (basil): Botany, cultivation, pharmaceutical properties, and biotechnology. Journal of Herbs, Spices and Medicinal Plants 13(3):123-150.

Mendes A, Almeida M, Felipe VFG, Furtado PMF, Feitosa CL, Días EF (2016).Influence of salinity on the development of the banana colonised by arbuscular mycorrhizal fungi. Revista Ciencia Agronómica 47(3):421-428.

Mujica-Pérez Y, Fuentes-Martínez AG (2012). Efecto de la biofertilización con hongos micorrízicos arbusculares (HMA) en el cultivo del tomate en condiciones de estrés abiótico [Effect of biofertilization with arbuscular mycorrhizal fungi (AMF) in tomato cultivation under conditions of abiotic stress]. Cultivos Tropicales 33(4):40-46.

Murillo-Amador B, Yamada S, Yamaguchi T, Rueda-Puente E, ÁvilaSerrano N, García-HernándezJL, ... Nieto-Garibay A (2007). Influence of calcium silicate on growth, physiological parameters and mineral nutrition in two legume species under salt stress. Journal Agronomy CropScience 193(6):413-421.

Navarro A, Elia A, Conversa G, Campia P, Mastrorilli M (2012). Potted mycorrhizal carnation plants and saline stress: Growth, quality and nutritional plant responses. Scientia Horticulturae 140:131-139.

NOM-021-SEMARNAT (2000). Que establece las especificaciones de fertilidad, salinidad y clasificación de suelos. Estudios, muestreo y análisis. Secretaria de Medio ambiente y Recursos Naturales. Diario Oficial. Segunda Sección [That establishes the specifications of fertility, salinity and soil classification. Studies, sampling and analysis. Secretary of Environment and Natural Resources. Official diary. Second section.] México DF pp 12-13.

Parra-Rivero SM, Maciel-De Sousa NM, Sanabria-Chopite ME, Pineda J (2014). Anatomical description of the arbuscular mycorrhizal fungi colonization in two tree legumes. [Descripción anatómica de la colonización de hongos micorrízicos arbusculares en dos leguminosas arbóreas]. Revista Ciencias Forestales y del Ambiente 24(2):183-196.

Porras-Soriano A, Sorano-Marintin ML, Porras-Piedra A, Azcón P (2009). Arbuscular mycorrhizal fungi increased growth, nutrient uptake and tolerance to salinity in olive trees under nursery conditions. Journal of Plant Physiology 166(13):1350-1359.

Rivera R, Fernández F, Hernández A, Martín JR, Fernández K (2003). El manejo efectivo de la simbiosis micorrízica, una vía hacia la agricultura sostenible. Estudio de caso: El Caribe [The effective management of mycorrhizal symbiosis, a path towards sustainable agriculture. Case study: The Caribbean] Editorial Agustín García Marrero. La Habana, Cubapp 166.

Rodríguez YY, Noval BP, Fernández MF, Rodríguez PH (2004). Comparative study of behaviour of six arbuscular mycorrhizal fungi when colonize tomato plants (Lycopersicon esculentum M. var. 'Amalia'). Ecología Aplicada3(1-2):162-171.

Ruiz-Lozano JM, Aroca R (2010). Modulation of aquaporin genes by the arbuscular mycorrhizal symbiosis in relation to osmotic stress tolerance. In: Seckbach J, Grube M (Eds). Symbioses and stress: Joint ventures in biology, cellular origin, life in extreme habitats and astrobiology. Springer Science Business Media 17:359-374.

Ruiz-Lozano JM, Porcel R, Aroca R (2006). Does the enhanced tolerance of arbuscular mycorrhizal plants to water deficit involve modulation of drought-induced plant genes? New Phytologist 171(4):693-698.

Samperio RG (1997). Hidroponia Básica [Basic Hydroponics]. Editorial Diana, pp 176.

Seema HS, Garampalli RH (2015). Effect of arbuscular mycorrhizal fungi on growth and biomass enhancement in Piper longum L. (Piperaceae). International Journal of Current Microbiology and Applied Sciences 4(1):11-18.

SEMARNAT (2009). El Medio Ambiente en México: En Resumen 2009 [The Environment in Mexico: In Summary 2009] México. (www.semarnat.gob.mx) pp 20-23.

Sharifia M, Ghorbanlib M, Ebrahimzadehc H (2007). Improved growth of salinity stressed soybean after inoculation with salt pre-treated mycorrhizal fungi. Journal of Plant Physiology 164(9):11441151.

StatSoft Inc (2011). Statistica. System reference. StatSoft, Inc., Tulsa, Oklahoma, USApp 1098.

Swift CE (2002). Mycorrhiza and soil phosphorus levels. Retrieved 04 October 2016 from http://mining.state.co.us/SiteCollection Documents/MycorrhizaAndSoilPhosphorusLevels.pdf.

Tomar US, Daniel V, Shrivastava K, Panwar MS, Pant P (2010). 
1292

Comparative evaluation and antimicrobial activity of Ocimum basilicum L(Labiatae).Journal of Global Pharma Technology 2(5):49-53.

Utobo EB, Ogbodo EN, Nwogbaga AC (2011). Techniques for extraction and quantification of arbuscular mycorrhizal fungi. Libyan Agriculture Research Center Journal International 2(2):68-78.

Qiang-Sheng W, Ying-Ning Z, Xin-Hua H (2010). Contributions of arbuscular mycorrhizal fungi to growth, photosynthesis, root morphology and ionic balance of citrus seedlings under salt stress. Acta Physiologiae Plantarum 32(2):297-304.

Wimmer MA, Muehling KH, Läuchli A, Brown PH, Goldbach HE (2016). Interaction of salinity and boron toxicity in wheat (Triticum aestivum L.) [en línea]. In: Horst WJ et al. (Eds). Plant Nutrition, Springer Netherlands pp $426-427$.

Wu QS, Zou YN, HeXH (2010). Contributions of arbuscular mycorrhizal fungi to growth, photosynthesis, root morphology and ionic balance of citrus seedlings under salt stress. Acta Physiologiae Plantarum 32:297304.
Yamasaki S, Dillenburg L (1999). Measurements of leaf relative water content in Araucaria angustifolia. Revista Brasileira de Fisiología Vegetal 11(2):69-75.

Yamato M, Ikeda S, Iwase K (2008). Community of arbuscular mycorrhizal fungi in coastal vegetation on Okinawa Island and effect of the isolated fungi on growth of sorghum under salt-treated conditions. Mycorrhiza 18(5):241-249.

Zamudio-González B, López-Pérez L, Alcántara-González, G, GonzálezEguiarte DR, Ruiz-Corral JA, Castellanos JZ (2004). Delimitación de áreas salinas en el distrito de riego de Caborca [Delimitation of salt areas in the irrigation district of Caborca] Sonora, México. Terra Latinoamericana 22(1):91-97. 